\title{
Perspektywy rozwoju zawodu doradcy restrukturyzacyjnego
}

\section{Wprowadzenie}

Niniejszy artykuł stanowi próbę przeanalizowania zawodu doradcy restrukturyzacyjnego, aby określić kierunki rozwoju prawa w tym zakresie w Polsce. W tym celu niezbędne jest zbadanie dotychczasowej ewolucji zawodu syndyka masy upadłości oraz procesu przekształcenia go w zawód doradcy restrukturyzacyjnego. Kulminacją tych rozważań jest stwierdzenie, czy w obecnym kształcie zawód ten ma charakter zawodu zaufania publicznego zgodny z art. 17 ust. 1 Konstytucji Rzeczypospolitej Polskiej ${ }^{1}$. Analiza pozwoli odpowiedzieć na pytania, jakie jeszcze kwestie związane z wykonywaniem zawodu doradcy restrukturyzacyjnego powinny być uregulowane przez ustawodawcę.

Dla pełniejszego zrozumienia tematu istotne jest także dokonanie analizy prawnoporównawczej. Wgląd w ustawodawstwo Federalnej Republiki Niemiec pozwoli wyraźnie zaznaczyć rozmiar przemian, jakie przeszło prawo upadłościowe w Polsce na przestrzeni ostatnich lat. Natomiast analiza prawa Unii Europejskiej (UE) pozwoli nakreślić europejskie tendencje rozwoju przyszłych rozwiązań w omawianym temacie.

Należy wskazać, że status syndyka masy upadłości od lat sprawiał problemy zarówno praktykom, jak i przedstawicielom nauki. Do dziś

* Filip Zygmunt Wichrowski, mgr, Uniwersytet Warmińsko-Mazurski w Olsztynie, e-mail: filipwichrowski@gmail.com, https://orcid.org/0000-0002-0112-9725.

${ }^{1}$ Konstytucja Rzeczypospolitej Polskiej z dnia 2 IV 1997 r. (Dz.U. Nr 78, poz. 483 ze zm.), dalej „Konstytucja RP” lub „Konstytucja”. 
nieuregulowanym zagadnieniem pozostaje kompleksowe określenie zasad funkcjonowania zawodu doradcy restrukturyzacyjnego.

Jedną z kwestii nieuregulowanych zarówno w Polsce, jak i w Niemczech jest istnienie i funkcjonowanie samorządów zawodowych syndyków masy upadłości (doradców restrukturyzacyjnych). Istotnym problemem jest między innymi sprawowanie władztwa administracyjnego $\mathrm{w}$ postaci sądownictwa dyscyplinarnego oraz brak regulacji w zakresie etyki wykonywania tych zawodów.

\section{Ewolucja zawodu syndyka masy upadłości w Polsce}

Analizując rozwój prawa upadłościowego po 1934 r., należy wskazać, że zawód syndyka masy upadłości przeszedł znaczącą przemianę. Ustawodawca, kończąc okres międzydzielnicowego prawa konkursowego, uchwalił przepisy otwierające nowy rozdział prawa upadłościowego w Polsce ${ }^{2}$. Były to: Rozporządzenie Prezydenta Rzeczypospolitej z dnia 24 października 1934 r. Prawo upadłościowe ${ }^{3}$ oraz Rozporządzenie Prezydenta Rzeczypospolitej z dnia 24 października 1934 r. Prawo o postępowaniu układowym ${ }^{4}$. Artykuł 14 Prawa upadłościowego wskazywał, że uwzględniając wniosek o ogłoszenie upadłości, sąd wyda postanowienie, w którym między innymi wyznaczy sędziego-komisarza oraz syndyka upadłości. Przepisy te nie zawierały jednak żadnych postanowień odnoszących się do kwalifikacji syndyka, pozostawiając sądowi całkowitą wolność w zakresie wyboru odpowiedniej osoby do sprawowania tej funkcji. Pewne wskazówki dotyczące kwalifikacji kandydata na stanowisko syndyka można było natomiast odnaleźć w polskim piśmiennictwie. Wskazywano przede wszystkim, że kandydat na syndyka powinien mieć odpowiednie zdolności organizacyjne oraz wykształcenie prawnicze lub ekonomiczne. Podkreślano, że z jednej strony syndyk musi mieć dużą wiedzę z zakresu prawa upadłościowego, z drugiej zaś musi nie tylko charakteryzować się znajomością ogólnych procesów gospodarczych, ale i posiadać rozeznanie w zakresie prowadzonego przez upadłego konkretnego rodzaju działalności gospodarczej. Wskazywano, że syndyk musi być osobą o nieposzlakowanej opinii

${ }^{2}$ P. Feliga, Stanowisko prawne syndyka w procesie dotyczacym masy upadłości, Warszawa 2013, s. 14.

${ }^{3}$ Dz.U. Nr 93, poz. 834.

${ }^{4}$ Dz.U. Nr 93, poz. 836. 
i dawać gwarancję prawidłowego wykonywania swoich obowiązków ${ }^{5}$. W związku z tym podnoszono, że dobrymi kandydatami na stanowisko syndyka masy upadłości są osoby z grona radców prawnych, adwokatów, ekonomistów, księgowych lub biegłych rewidentów ${ }^{6}$. Sugerowano, że osoba wykonująca funkcję syndyka nie powinna być powiązana $\mathrm{w}$ jakikolwiek sposób z upadłym, np. przez pokrewieństwo, powinowactwo czy przez fakt sprawowania funkcji zarządczych, nadzorczych lub bycia wspólnikiem w upadłej spółce ${ }^{7}$.

W okresie Polskiej Rzeczypospolitej Ludowej przepisy te ze względu na nowy system polityczno-gospodarczy państwa nie znajdowały szczególnego zastosowania ${ }^{8}$. Rozwój prawa upadłościowego przyniosły dopiero przemiany gospodarczo-polityczne lat dziewięćdziesiątych XX w. Mając na celu dostosowanie prawa upadłościowego do ówcześnie panujących realiów, rozpoczęto sukcesywne nowelizowanie przedwojennego prawa upadłościowego. Pomimo wprowadzenia zmian w dużej mierze zachowało ono swój oryginalny charakter ${ }^{9}$. Rozwój wolnego rynku w Polsce wymusił w naturalny sposób wzrost zainteresowania tą dziedziną prawa i stworzył zapotrzebowanie na, częściowo już wówczas zapomniany, zawód syndyka masy upadłości. Krytycznie oceniano sprawowanie funkcji syndyka przez radców prawnych lub adwokatów, którzy wykonywali te czynności jako dodatkowe zajęcia, obok podstawowych usług świadczenia pomocy prawnej. Wskazywano na potrzebę specjalistycznego przygotowania zawodowego kandydatów na stanowiska syndyków. W związku z tym osoby chętne do sprawowania tej funkcji pozyskiwano najczęściej przez organizowanie specjalnych kursów ${ }^{10}$. Brak sformalizowanych wymagań sprawiał jednak, że w poszczególnych sądach upadłościowych stosowano różne kryteria doboru kandydatów na to stanowisko i pozyskiwano ich z różnych grup zawodowych ${ }^{11}$. Często $\mathrm{w}$ sądach upadłościowych tworzono też listy kandydatów na syndyków, mimo że ustawa nie normowała takiego

${ }^{5}$ A. Pokora, Stanowisko prawne syndyka masy upadłości, „Rejent” 1997, nr 7-8(75-76), s. 192.

${ }^{6}$ Ibidem, s. 194.

${ }^{7}$ J. Jacyszyn, Syndyk masy upadłości, „Rejent” 1993, nr 3-4, s. 38.

${ }^{8}$ R. Adamus, Zarys historii źródeł prawa upadłościowego w Polsce, "Jurysta" 2009, nr 7, s. 28.

${ }^{9}$ W. Podel, Geneza instytucji syndyka masy upadłości na tle rozwoju regulacji prawa upadłościowego, „Rocznik Towarzystwa Naukowego Płockiego” 2013, nr 5, s. 186.

$10 \mathrm{~J}$. Broll, Prawo upadłościowe w świetle praktyki sądowej, Warszawa 1995, s. 92.

${ }^{11}$ Ibidem, s. 95. 
obowiązku' ${ }^{12}$. Ze względu na głosy krytyczne odnoszące się do kwalifikacji oraz stabilizacji zawodowej syndyków, niezbędna była dalsza reforma prawa upadłościowego ${ }^{13}$.

Zmiany w tym zakresie przyniosła nowelizacja prawa upadłościowego, na podstawie której minister sprawiedliwości wydał rozporządzenie w sprawie szczególnych kwalifikacji oraz warunków wymaganych od kandydatów na syndyków upadłości z dnia 16 kwietnia 1998 r. ${ }^{14}$ Przepisy tego rozporządzenia wskazywały, że osoba fizyczna kandydująca na syndyka masy upadłości powinna mieć między innymi wyższe wykształcenie i co najmniej pięcioletni staż pracy na stanowiskach kierowniczych. Osoba taka powinna się wykazać znajomością prawa gospodarczego, cywilnego, pracy oraz finansów. Rozporządzenie stanowiło, że kandydat na syndyka nie może być karany za popełnione umyślnie przestępstwo przeciwko mieniu i nie może figurować w wykazie osób, wobec których orzeczono zakaz prowadzenia działalności gospodarczej. Adwokat, radca prawny i biegły rewident zwolnieni byli ze spełniania kryterium praktyki zawodowej na stanowisku kierowniczym. Listy kandydatów na syndyków prowadzone były przez prezesów sądów wojewódzkich. Osoby ubiegające się o wpis zostawały tam umieszczane po wykazaniu posiadania wymaganych kwalifikacji.

Wskazane przepisy zmusiły duże grono osób wykonujących zawód syndyka do przekwalifikowania się ze względu na niespełnianie stawianych wymagań lub do podjęcia trudu uzyskania wyższego wykształcenia. W stosunku do osób, które miały wykształcenie średnie przed dniem wejścia w życie rozporządzenia i pełniły funkcję syndyka przez okres co najmniej dwóch lat, możliwe było odstąpienie od cenzusu posiadanego wykształcenia, jeżeli spełniona była reszta wskazanych wymagań.

Ze względu na to, że podjęte próby znowelizowania przedwojennego prawa upadłościowego i dostosowania go do nowych realiów gospodarczych nie przyniosły oczekiwanych efektów, ustawodawca uchwalił Ustawę z dnia 28 lutego 2003 r. Prawo upadłościowe i napraw$\mathrm{cze}^{15}$, obecnie Prawo upadłościowe ${ }^{16}$. Ustawa ta pozostawiała w dalszym ciągu uznaniu sądu upadłościowego kwestię doboru syndyka do konkretnego postępowania upadłościowego. Artykuł 157 pr.up. jednak

\footnotetext{
${ }_{12}$ M. Allerhand, Prawo upadłościowe z komentarzem, Bielsko-Biała 1994, s. 215.

${ }^{13}$ J. Jacyszyn, op. cit., s. 44.

${ }^{14}$ Dz.U. Nr 55, poz. 359.

${ }^{15}$ Dz.U. Nr 60, poz. 535.

${ }^{16}$ Tekst jedn. Dz.U. 2020, poz. 1228 ze zm., dalej „pr.up.”.
} 
wyraźnie określał, że osoba taka musi posiadać odpowiednią licencję. Obowiązek ten został skonkretyzowany dopiero Ustawą z dnia 15 czerwca 2007 r. o licencji syndyka ${ }^{17}$. Do czasu uchwalenia tego aktu w zakresie kwalifikacji wymaganych od syndyka zachowywało moc dotychczasowe rozporządzenie ministra sprawiedliwości. W literaturze natomiast zaczęły się pojawiać postulaty, aby zawód syndyka powiązać z wymogiem posiadania wykształcenia prawniczego, ponieważ postępowanie upadłościowe jest postępowaniem sądowym. Wskazywano, że w porównaniu z zawodem komornika sądowego syndyk potrzebuje dużej wiedzy prawniczej ${ }^{18}$.

\section{Pozycja prawna zawodu syndyka/ doradcy restrukturyzacyjnego}

Ustawa o licencji syndyka określa nowe, wyższe wymagania kwalifikacyjne dla osób chcących sprawować tę funkcję. W tym kontekście ustawa potwierdza między innymi, że syndyk musi nie tylko mieć wyższe wykształcenie, ale i tytuł magistra. Istotnym nowym wymaganiem jest zdanie egzaminu przygotowanego przez Ministerstwo Sprawiedliwości. Spośród wszystkich wymagań określonych w art. 3 nowej ustawy te dwa sprawiły, że grono osób, które dotychczas sprawowały funkcję syndyka masy upadłości, uległo znacznemu zmniejszeniu. W dniu wejścia aktu w życie na dotychczasowych listach kandydatów na syndyków figurowało 5270 osób ${ }^{19}$. Obecnie, po czternastu latach obowiązywania ustawy, na ministerialnej liście osób posiadających licencje znajduje się ponad 1500 osób $^{20}$. Ustawa nie przewiduje żadnej formy zwolnienia z wymogu zdania egzaminu. Ponadto Trybunał Konstytucyjny nie uznał prawa osób dotychczas wykonujących tę funkcję z tytułu praw nabytych ${ }^{21}$.

${ }^{17}$ Dz.U. Nr 123, poz. 850, w brzmieniu pierwotnym ze zm. (tekst jedn. Dz.U. 2014, poz. 776).

${ }^{18}$ A. Hrycaj, Syndyk masy upadłości, Poznań 2006, s. 73.

19 A. Gnys, Konsekwencje wejścia w życie ustawy o licencji syndyka, "Monitor Prawniczy” 2008, nr 5, s. 274.

${ }^{20}$ Lista osób posiadających licencję doradcy restrukturyzacyjnego, https://www. arch.ms.gov.pl/pl/lista-osob-posiadajacych-licencje-doradcy-restrukturyzacyjnego/\# (dostęp: 16 III 2021).

${ }^{21}$ Wyrok Trybunału Konstytucyjnego (TK) z 26 IV 2013 r., sygn. K 15/10, LEX nr 1286340. 
Pomimo określenia kwalifikacji zawodowych syndyków na dość wysokim poziomie ustawodawca nie wskazał konkretnego rodzaju studiów, jakie mają odbyć kandydaci na syndyków. W związku z tym zawód pozostał otwarty dla osób nieposiadających wykształcenia prawniczego. Niemniej jednak w literaturze wyrażano pogląd, że osoba sprawująca funkcję syndyka powinna charakteryzować się wysokimi kwalifikacjami. Podkreśla się, że syndyk powinien posiadać wiedzę zarówno z zakresu prawa, jak i ekonomii. Sugeruje się, aby osoba wyznaczana na to stanowisko znała specyfikę oraz charakter przedsiębiorstwa upadłego ${ }^{22}$.

Nowelizacja prawa upadłościowego, która weszła w życie od 1 stycznia 2016 r., wprowadziła duże zmiany w zakresie statusu zawodowego syndyków. Zmieniając ustawę o licencji syndyka ${ }^{23}$, nie tylko zastąpiono jej dotychczasowy tytuł nowym - o licencji doradcy restrukturyzacyjnego, ale także rozszerzono zakres kompetencji osób posiadających dotychczas licencję syndyka ${ }^{24}$. W związku z tym można zaryzykować stwierdzenie, że z chwilą wprowadzenia nowelizacji formalnie powstał w Polsce nowy rodzaj zawodu regulowanego, jakim jest doradca restrukturyzacyjny. Zgodnie z art. 2 ust.lic. licencja doradcy restrukturyzacyjnego uprawnia do wykonywania, tak jak to było przed nowelizacją, czynności syndyka, nadzorcy i zarządcy. Istotnym novum jest to, że osoba posiadająca licencję doradcy restrukturyzacyjnego może wykonywać czynności doradztwa restrukturyzacyjnego poprzez udzielanie porad, opinii i wyjaśnień oraz świadczenie innych usług z zakresu restrukturyzacji i upadłości. W tym zakresie wskazuje się, że relacja pomiędzy doradcą restrukturyzacyjnym a jego klientem, który na zasadach dobrowolności korzysta z usług doradcy, przypomina udzielanie pomocy prawnej przez adwokata ${ }^{25}$.

Istotne jest ponadto, że znowelizowany art. $87 \S 1$ Kodeksu postępowania cywilnego ${ }^{26}$ przewiduje, iż osoba posiadająca licencję doradcy restrukturyzacyjnego może być pełnomocnikiem strony w procesach dotyczących spraw restrukturyzacji i upadłości. W ramach tego uprawnienia

${ }^{22}$ I. Gil, Sytuacja prawna syndyka masy upadłości, Warszawa 2006, s. 4.

${ }^{23}$ Zob. art. 440 pkt 3 Ustawy z dnia 5 V 2015 r. Prawo restrukturyzacyjne (Dz.U., poz. 978 ze zm).

${ }^{24}$ Tekst jedn. Dz.U. 2020, poz. 242 ze zm., dalej "ust.lic.”.

${ }^{25}$ M. Waberski, Tajemnica zawodowa doradcy restrukturyzacyjnego, "Palestra” 2018, nr 7-8, s. 68 .

${ }^{26}$ Ustawa z dnia 17 XI 1964 r. Kodeks postępowania cywilnego (tekst jedn. Dz.U. 2020, poz. 1575), dalej „k.p.c.”. 
nie może ona wprawdzie występować przed Sądem Najwyższym, ale może reprezentować stronę przed sądami powszechnymi ${ }^{27}$.

W związku z tym doradca restrukturyzacyjny, w odróżnieniu od syndyka masy upadłości, nie jest już tylko funkcją wewnątrz postępowania upadłościowego. Obecne uregulowania kształtują doradcę restrukturyzacyjnego jako oddzielny zawód regulowany, w ramach którego osoba fizyczna posiadająca licencję prowadzi pozarolniczą działalność gospodarczą i wykonuje czynności w ramach działalności gospodarczej zgodnie z art. 2 ust. 4 ust.lic. Tym samym ustawodawca odpowiada na stawiane od lat pytania o status osoby wykonującej zawód syndyka w Polsce ${ }^{28}$.

Pomimo rozwoju ustawodawstwa wielu kwestii związanych z wykonywaniem zawodu doradcy restrukturyzacyjnego nie określono dostatecznie. Do rozstrzygnięcia pozostają między innymi sprawy szkolenia zawodowego czy zasady wykonywania zawodu.

\section{Samorząd zawodowy doradców restrukturyzacyjnych}

Powyżej wskazane zagadnienia, które potrzebują dokładniejszych regulacji, są ściśle powiązane z kwestią samorządu zawodowego. Porównując zawód doradcy restrukturyzacyjnego z innymi zawodami regulowanymi w Polsce, takimi jak radca prawny czy adwokat, to właśnie samorząd zawodowy pełni istotną rolę $\mathrm{w}$ systemie szkolenia zawodowego, zarówno przygotowującego do egzaminu zawodowego, jak i utrzymującego kwalifikacje członków samorządu na wysokim poziomie.

Żadna z dotychczas obowiązujących ustaw nie nakładała na osoby wykonujące zawód syndyka lub doradcy restrukturyzacyjnego obowiązku zrzeszania się w samorządach zawodowych. Pomimo to osoby wykonujące te zawody już od lat dziewięćdziesiątych zrzeszają się w różnego rodzaju organizacjach. Pośród wielu regionalnych i ogólnopolskich instytucji tego typu warto wymienić założoną w 2001 r. Ogólnopolską Federację Doradców Restukturyzacyjnych i Syndyków czy utworzoną w 2010 r. Krajową Izbę Doradców Restrukturyzacyjnych, której struktura organizacyjna charakterem przypomina samorząd zawodowy np. radców

${ }^{27}$ Por. J. Gudowski, Art. 87, w: Kodeks postępowania cywilnego. Komentarz, t. 1: Postępowanie rozpoznawcze, pod red. T. Erecińskiego, Warszawa 2016, pkt 23.

${ }^{28}$ Por. A. Hrycaj, op. cit., s. 29-34. 
prawnych. Organizacje te oferują swoim członkom między innymi szkolenia zawodowe, ponadto aktywnie uczestniczą w procesie kształtowania prawa upadłościowego i restrukturyzacyjnego. Wychodzą również z inicjatywami kodyfikacji Kodeksu Etyki Doradcy restrukturyzacyjnego ${ }^{29}$.

Podmioty te nie są samorządami zawodowymi w rozumieniu art. 17 ust. 1 Konstytucji RP. Nie zostały powołane do życia przez ustawodawcę, a przynależność do nich jest dobrowolna. Duża część osób obecnie wykonujących zawód doradcy restrukturyzacyjnego nie przynależy do żadnej organizacji zawodowej zrzeszającej specjalistów z tej dziedziny. Istniejące stowarzyszenia nie mają uprawnień władczych w stosunku do swoich członków. Co więcej, nie mają one żadnego wpływu na to, kto posiada licencję zawodowa, i nie mogą kontrolować osób wykonujących zawód doradcy w zakresie ich kwalifikacji. Kwestia etyki wykonywania zawodu pozostaje w dużej mierze poza ich zasięgiem, biorąc pod uwagę, że wszelkie kodeksy zasad wykonywania zawodu mają charakter aktu wewnętrznie obowiązującego ${ }^{30}$.

\section{Propozycje Unii Europejskiej zmian w prawie upadłościowym}

Kwestia upadłości i restrukturyzacji przedsiębiorstw jest zagadnieniem, którym od dłuższego czasu zainteresowane są także organy UE. Działalność gospodarcza przedsiębiorców wykraczająca poza granice jednego państwa stała się codziennością. W związku z tym do częstszych należą sytuacje, w których przedsiębiorca staje się wierzycielem spółki upadłej poza granicami kraju. Spotyka się wtedy z gąszczem niezrozumiałych dla niego regulacji upadłościowych. Stan upadłości dla przedsiębiorcy wiąże się z niepewnością i długotrwałym ryzykiem. Dlatego niezbędna jest ingerencja ustawodawcy europejskiego.

Dyrektywa Parlamentu Europejskiego i Rady nr 2019/1023 z dnia 20 czerwca 2019 r. przynosi zmiany w prawie upadłościowym, które w Polsce są już od dawna sukcesywnie wprowadzane ${ }^{31}$. Zgodnie

\footnotetext{
${ }^{29}$ Kodeks Etyki Doradcy restrukturyzacyjnego, http://kidr.pl/wp-content/uploads/ 2016/01/KODEKS-ETYKI-Doradcy-Restrukturyzacyjnego.pdf (dostęp: 29 III 2021).

${ }^{30}$ Por. wyrok TK z 18 II 2004 r., sygn. P 21/02, OTK-A 2004, nr 2, poz. 9, pkt III.10 i III.15.

${ }^{31}$ Dyrektywa Parlamentu Europejskiego i Rady (UE) 2019/1023 z dnia 20 VI 2019 r. w sprawie ram restrukturyzacji zapobiegawczej, umorzenia długów i zakazów prowadzenia działalności oraz w sprawie środków zwiększających skuteczność postępowań
} 
z pkt 85 preambuły dyrektywy 2019/1023 niezbędne jest utrzymanie i zwiększenie przejrzystości oraz przewidywalności postępowań restrukturyzacyjnych i upadłościowych. Ich wyniki powinny sprzyjać podtrzymywaniu działalności przedsiębiorstw, a także powinny pozwalać przedsiębiorcom na drugą szansę lub umożliwiać skuteczną likwidację nierentownych przedsiębiorstw. Niezbędne jest również zmniejszenie przewlekłości postępowań upadłościowych w wielu państwach członkowskich, gdyż prowadzi to do braku pewności prawa dla wierzycieli i inwestorów oraz do niskich stóp odzysku.

W wąskim zakresie dyrektywa 2019/1023 odnosi się do sposobu wykonywania zawodu syndyka masy upadłości. Zwraca się między innymi uwagę na kwestie szkoleń z zakresu prawa upadłościowego i restrukturyzacyjnego. Artykuł 26 ust. 1 lit. a dyrektywy 2019/1023 wskazuje, że państwa członkowskie zapewniają aby nadzorcy powoływani przez organ sądowy lub administracyjny w postępowaniach dotyczących restrukturyzacji, niewypłacalności i umorzenia długów odbyli odpowiednie szkolenia i mieli wiedzę fachową niezbędną do wykonywania swoich obowiązków. Zapis ten jest spójny z brzmieniem art. 2 ust. 5 ust.lic., który stanowi, że osoba fizyczna posiadająca licencję doradcy restrukturyzacyjnego jest obowiązana do kształcenia ustawicznego w celu podnoszenia kwalifikacji i umiejętności zawodowych.

Należy zwrócić uwagę, że pkt 87 preambuły do dyrektywy 2019/1023 stanowi, iż odbycie odpowiednich szkoleń oraz zdobycie kwalifikacji i wiedzy fachowej przez nadzorców mogłoby również mieć miejsce podczas wykonywania ich zawodu. W dalszej części tego punktu wskazuje się, że państwa członkowskie nie powinny mieć obowiązku same zapewniać potrzebnych szkoleń. Zadanie to może być delegowane na stowarzyszenia zawodowe lub inne organizacje.

Wprowadzając powyższe regulacje, ustawodawca unijny wskazuje wyraźnie na potrzebę ustanowienia na poziomie krajowym zorganizowanego systemu szkoleń doradców restrukturyzacyjnych. Nie jest przy tym istotne, czy zadanie to będzie wypełniane bezpośrednio przez organy państwa członkowskiego czy przez odpowiedni samorząd zawodowy.

Następnym zagadnieniem poruszanym przez ustawodawcę unijnego jest potrzeba stworzenia zasad wykonywania zawodu doradcy restrukturyzacyjnego. Artykuł 27 ust. 3 dyrektywy 2019/1023 stanowi,

dotyczących restrukturyzacji, niewypłacalności i umorzenia długów, a także zmieniająca dyrektywę (UE) 2017/1132 (dyrektywa o restrukturyzacji i upadłości), dalej „dyrektywa 2019/1023" (Dz.Urz. UE L 172 z dnia 26 VI 2019 r., s. 18). 
że państwa członkowskie mogą zachęcać nadzorców do opracowywania i przestrzegania kodeksów postępowania. Przepis ten wyraźnie wskazuje, że zasady wykonywania zawodu mają być ustalone samodzielnie, przez grupę osób wykonującą zawód doradcy restrukturyzacyjnego. Do tego celu niezbędne jest istnienie jednolitych struktur samorządu zawodowego zrzeszającego wszystkich przedstawicieli danego zawodu.

Przynależność do samorządu zawodowego, który posiada uprawnienia władcze w stosunku do swoich członków, tak jak to jest w przypadku np. adwokatów i radców prawnych, umożliwiłaby także pełniejszą implementację art. 27 ust. 1 dyrektywy 2019/1023. Przepis ten stanowi, że państwa członkowskie ustanawiają odpowiednie mechanizmy nadzorcze i regulacyjne w celu zapewnienia skutecznego nadzoru nad pracą nadzorców, aby ich usługi były świadczone w sposób efektywny i kompetentny oraz - w odniesieniu do zaangażowanych stron - bezstronny i niezależny. Mechanizmy te obejmują również środki zapewniające możliwość rozliczenia nadzorców, którzy nie dopełnili swoich obowiązków. W tym zakresie istnieje w Polsce nadzór odpowiednich sądów i ministra sprawiedliwości. Funkcjonowanie jednolitego samorządu zawodowego doradców restrukturyzacyjnych mogłoby jednak stanowić dobre uzupełnienie systemu kontroli prawidłowego wykonywania zawodu przez doradców restrukturyzacyjnych.

\section{Stan prawny w RFN}

Problem braku regulacji prawnych w stosunku do syndyka masy upadłości jest także od lat dyskutowany w RFN. Federalny Trybunał Konstytucyjny uznał w 2004 r. syndyka masy upadłości za zawód wykonywany w celach zarobkowych ${ }^{32}$. Od czasu opublikowania powyższego orzeczenia w dalszym ciągu trwa w Niemczech debata nad potrzebą uchwalenia przepisów kształtujących zasady wykonywania zawodu syndyka $^{33}$. Zauważa się konieczność szczegółowego uregulowania m.in. kwestii: kwalifikacji zawodowych, wykształcenia zawodowego, wyboru konkretnych osób na stanowiska syndyka, nadzoru nad prawidłowym wykonywaniem zawodu oraz potrzeby jednolitego samorządu

${ }^{32}$ Wyrok Federalnego Trybunału Konstytucyjnego z 3 VII 2004 r., sygn. 1 BVR 135/00; 1 BVR 1086/01, NZI 2004, s. 574.

${ }^{33} \mathrm{H}$. Vallender, Die Zeit ist reif - Plädoyer für eine Berufsordnung für Insolvenzverwalter, NZI 2017, s. 641. 
zawodowego syndyków masy upadłości, który miałby rzeczywisty wpływ na powyższe zagadnienia ${ }^{34}$.

W RFN kwestie kwalifikacji osoby wybieranej na stanowisko syndyka są pozostawione $w$ dużej mierze uznaniu sądu, który wydaje zgodnie z $\S 27$ ust. 1 niemieckiej ustawy o postępowaniu upadłościowym ${ }^{35}$ postanowienie o ogłoszeniu otwarcia postępowania upadłościowego. Paragraf 56 tego aktu jest jedyną normą wskazującą na sposób wyboru syndyka. Stanowi on, że na stanowisko syndyka masy upadłości w konkretnym postępowaniu jest powoływana odpowiednia osoba fizyczna, niezależna od wierzycieli i dłużnika, która pochodzi z kręgu osób gotowych do podjęcia funkcji syndyka. Osoba ta powinna w szczególności posiadać wiedzę i doświadczenie z zakresu prawa gospodarczego oraz upadłościowego ${ }^{36}$. W celu ułatwienia pracy sędziego w tym zakresie tworzone są listy preselekcyjne kandydatów na syndyków, którymi jednak sąd nie jest związany. Mają one pomóc mu odnaleźć odpowiednią osobę na stanowisko syndyka w konkretnym postępowaniu ${ }^{37}$. W literaturze wskazuje się, że w porównaniu z innymi krajami europejskimi w Niemczech cały czas brakuje państwowego systemu obiektywnie sprawdzającego i kontrolującego kwalifikacje osoby powoływanej na stanowisko syndyka ${ }^{38}$. Swego rodzaju gwarancją prawidłowości wykonywania tego zawodu jest praktyka powoływania na to stanowisko adwokatów, którzy specjalizują się w prawie gospodarczym, mają odpowiednie doświadczenie i zaplecze organizacyjno-techniczne ${ }^{39}$. Pomimo że jest to zawód zdominowany przez prawników, nie jest to jednak warunek sine qua non jego wykonywania ${ }^{40}$.

Podobnie jak w Polsce, syndycy w Niemczech, nie czekając na odgórny nakaz ustawodawcy, samodzielnie powołali stowarzyszenia zrzeszające osoby wykonujące tę profesję. Jednym z nich jest Verband Insolvenzverwalter Deutschlands e.V. (VID). Organizacja ta podejmuje działania na rzecz profesjonalnego wykonywania czynności przez syndyków masy

${ }^{34}$ Ibidem, s. 641-648.

${ }^{35}$ Insolvenzordnung z dnia 5 X 1994 r. (BGBl. I S. 2866 ze zm.).

${ }^{36}$ Por. U. Foerster, Insolvenzrecht, München 2014, s. 28.

${ }^{37}$ W. Delhaes, V. Römermann, § 56, w: Insolvenzordnung Kommentar, pod red. J. Nerlicha, V. Römermanna, München 2018, nb. 8.

${ }^{38}$ F. Frind, Zur Geltungsreichweite und Nutzen einer Berufsverordnung für Insolvenzverwalter, NZI 2018, s. 729.

${ }^{39}$ D. Andres, § 56, w: Insolvenzordnung, pod red. D. Andresa, R. Leithausa, München 2014, nb. 5.

${ }^{40}$ C. Kruth, Insolvenzverwaltung - Closed Shop für Juristen?, DStR 2018, s. 2218. 
upadłości. W tym celu uchwaliła ona dokument zatytułowany „Zasady prawidłowego wykonywania zawodu"41. Podnosi się jednak, że efektywność prowadzonych działań przez VID jest ograniczona jedynie do syndyków zrzeszonych w jej szeregach ${ }^{42}$, a podmiot ten zrzesza tylko jedną czwartą wszystkich osób wykonujących zawód syndyka ${ }^{43}$.

\section{Konstytucyjne uwarunkowania powołania samorządu zawodowego doradców restrukturyzacyjnych}

W Polsce prawo tworzenia samorządu zawodowego ustanawia art. 17 ust. 1 Konstytucji RP. Zgodnie z tym przepisem w drodze ustawy można tworzyć samorządy zawodowe, reprezentujące osoby wykonujące zawody zaufania publicznego i sprawujące pieczę nad należytym wykonywaniem tych zawodów w granicach interesu publicznego i dla jego ochrony. Zgodnie z tą regulacją powodem, dla którego państwo decyduje się na tworzenie takich podmiotów, jest między innymi potrzeba istnienia zorganizowanej reprezentacji środowiska osób wykonujących zawód zaufania publicznego. Należy jednak wskazać, że nie jest to czynnik decydujący. Funkcję tę mogą również spełniać stowarzyszenia, które nie potrzebują do swojego istnienia ingerencji państwa ani uprawnień władczych. Samorząd zawodowy zaspokaja z punktu widzenia państwa jeszcze inne istotne potrzeby, do których należą "potrzeba kontroli realizacji funkcji ochrony interesu publicznego podczas wykonywania czynności zawodowych, potrzeba zapewnienia właściwego wykonywania społecznie i publicznie istotnych zawodów w państwie", a także "potrzeba kontroli poczynań przedstawicieli zawodu pod względem etycznym" ${ }^{\prime 4}$.

Zgodnie z orzecznictwem Trybunału Konstytucyjnego treść art. 17 ust. 1 Konstytucji RP wyraźnie sugeruje daleko idącą swobodę ustawodawcy w zakresie tworzenia samorządów zawodowych. Konstytucja nie formułuje prawa do samorządu zawodowego. Użycie przez ustawodawcę sformułowania "w drodze ustawy można tworzyć samorządy zawodowe" jednoznacznie wskazuje, że nie jest to jego obowiązkiem ${ }^{45}$.

${ }^{41}$ Grundsätze ordnungsgemäßer Insolvenzverwaltung (GOI), https://www.vid.de/ wp-content/uploads/2016/09/goi-1-2016-vom-22.04.2016.pdf (dostęp: 11 VI 2021).

${ }^{42}$ H. Vallender, op. cit., s. 641.

${ }^{43}$ Ibidem, s. 646.

${ }^{44}$ H. Zięba-Załucka, Samorząd zawodowy w świetle Konstytucji RP, „Monitor Prawniczy” 2005, nr 10, s. 493.

${ }^{45}$ Wyrok TK z 30 XI 2011 r., sygn. K 1/10, OTK-A 2011, nr 9, poz. 99, pkt III.3.3. 
Niemniej w literaturze wskazuje się, że o ile tworzenie samorządów zawodowych nie jest obligatoryjne dla ustawodawcy, to jednak ich istnienie jest ściśle związane $\mathrm{z}$ wieloma ustrojowymi zasadami. Są to m.in.: zasada pomocniczości, zasada urzeczywistniania dobra wspólnego, zasada demokratycznego państwa prawnego, zasada sprawiedliwości społecznej ${ }^{46}$. Tak więc podejmując decyzję o powołaniu do życia konkretnego samorządu przewidzianego w art. 17 Konstytucji RP, ustawodawca tworzy "jedna z fundamentalnych instytucji polskiego porządku konstytucyjnego" ${ }^{\prime 7}$.

Należy więc zapytać, czym jest zawód zaufania publicznego i czy doradcę restrukturyzacyjnego można zakwalifikować jako taki zawód,

Określenie „zawód zaufania publicznego" zawarte w art. 17 ust. 1 Konstytucji RP jest stosunkowo nowym terminem dla nauki prawa konstytucyjnego i nie ma legalnej definicji. Podnosi się jednak, że treść przywołanego przepisu jest utożsamiana z wolnymi zawodami, które tradycyjnie były wykonywane na własny rachunek w sensie gospodarczym ${ }^{48}$. Działalność taka charakteryzuje się ponoszeniem całkowitej odpowiedzialności za swoje decyzje i brakiem przełożonych. Prowadzenie takiego zajęcia związane jest z przyjmowaniem indywidualnych zleceń.

W toku prac nad treścią Konstytucji RP podnoszono, że charakter zawodu zaufania publicznego mają zawody prawnicze i medyczne ${ }^{49}$. W literaturze wskazuje się cechy, jakie powinien mieć dany zawód, aby można go było uznać za zawód zaufania publicznego. Cechami takimi będą m.in.: intelektualny charakter pracy, niepodleganie hierarchii urzędniczej czy obowiązek zachowania tajemnicy zawodowej ${ }^{50}$. Ma to związek z tym, że osobom wykonującym zawód zaufania publicznego powierzane są dane dotyczące życia prywatnego obywateli. Osoby takie

\footnotetext{
${ }^{46}$ A. Trubalski, Samorzady zawodów zaufania publicznego na przykładzie samorządu radców prawnych, "Studia Iuridica Lublinensia” 2014, nr 21, s. 227.

${ }^{47}$ M. Szydło, Art. 17 Konstytucji RP, w: Konstytucja RP. Komentarz do art. 1-86, pod red. M. Safjana, L. Boska, Warszawa 2016, nb. 17.

${ }^{48}$ M. Kulesza, Pojęcie zawodu zaufania publicznego, w: Zawody zaufania publicznego a interes publiczny - korporacyjna reglamentacja versus wolność wykonywania zawodu, Warszawa 2002, s. 26.

${ }^{49}$ H. Zięba-Załucka, op. cit., s. 493.

${ }^{50}$ K. Dąbrowski, Samorzad zawodowy i gospodarczy, w: Administracja publiczna i prawo administracyjne w zarysie, pod red. M. Karpiuka, J. Kowalskiego, Warszawa 2013, s. 221. Zob. też K. Wojtczak, Zawód i jego prawna reglamentacja. Studium z zakresu materialnego prawa administracyjnego, Poznań 1999, s. 111.
} 
działają często w sytuacji wystąpienia niebezpieczeństwa dla dóbr jednostki, takich jak zdrowie, wolność, godność czy dobre imię ${ }^{51}$. Zwraca się uwagę na quasi-misyjny charakter tych zawodów ${ }^{52}$. Wspomina się także o odpowiednim wykształceniu, wysokim poziomie wiedzy oraz przygotowaniu praktycznym ${ }^{53}$. Takie postrzeganie zawodów zaufania publicznego potwierdzono w orzecznictwie TK. Dodatkowo TK wskazuje, że "wykonywanie zawodu zaufania publicznego określane jest normami etyki zawodowej, szczególną treścią ślubowania, tradycją korporacji zawodowej"54. "Zawody zaufania publicznego wykonywane są [...] w sposób założony i społecznie aprobowany, o ile ich wykonywaniu towarzyszy realne zaufanie publiczne. Na zaufanie to składa się szereg czynników, wśród których na pierwszy plan wysuwają się: przekonanie o zachowaniu przez wykonującego ten zawód dobrej woli, właściwych motywacji, należytej staranności zawodowej, oraz wiara w przestrzeganie wartości istotnych dla profilu danego zawodu. $W$ odniesieniu do wykonywania prawniczych zawodów zaufania publicznego do istotnych wartości należy pełne i integralne respektowanie prawa, w tym zwłaszcza przestrzeganie wartości konstytucyjnych (w ich hierarchii) oraz dyrektyw postępowania" 55 .

Wymienione charakterystyczne cechy można w większości przyporządkować do zawodu doradcy restrukturyzacyjnego. Zawód ten wykonywany jest przez osoby, które muszą wykazać się odpowiednim wykształceniem, wiedzą i praktyką zawodową. Wymogi stawiane kandydatom podczas egzaminu na licencję doradcy restrukturyzacyjnego są bardzo wysokie. Niewątpliwie są one ograniczeniem wolności wyboru i wykonywania zawodu zagwarantowanego w art. 56 ust. 1 Konstytucji RP. Tym samym ustawodawca zwraca uwagę na to, jak ważny jest ten zawód z punktu widzenia interesu publicznego. Zgodnie z art. 22 ustawy zasadniczej tylko $\mathrm{z}$ takich pobudek możliwe jest ograniczenie wolności działalności gospodarczej. Ponadto zgodnie z art. 31 ust. 3 Konstytucji ograniczenia w zakresie korzystania z konstytucyjnych wolności i praw mogą być ustanawiane tylko wtedy, gdy są konieczne w demokratycznym państwie dla jego bezpieczeństwa lub porządku publicznego, bądź

${ }^{51}$ H. Zięba-Załucka, op. cit., s. 493.

${ }^{52}$ W.J. Wołpiuk, Zawód zaufania publicznego z perspektywy prawa konstytucyjnego, w: Zawody zaufania publicznego a interes publiczny..., s. 22.

${ }_{53}$ A. Trubalski, op. cit., s. 230-231.

${ }^{54}$ Wyrok TK z 7 V 2002 r., sygn. SK 20/00, OTK-A 2002, nr 3, poz. 29.

${ }^{55}$ Wyrok TK z 2 VII 2007 r., sygn. K 41/05, OTK-A 2007, nr 7, poz. 72. 
dla ochrony środowiska, zdrowia i moralności publicznej, albo wolności i praw innych osób. W związku z tym należy sądzić, że dotychczasowe sukcesywne zwiększanie barier wejścia do zawodu doradcy restrukturyzacyjnego jest objawem szczególnego charakteru tego zawodu z punktu widzenia państwa.

Należy zwrócić uwagę, że osoby otrzymujące licencję doradcy restrukturyzacyjnego składają ślubowanie o szczególnej treści. Zgodnie z art. 15 ust. 1 ust.lic. rota ślubowania ma następujące brzmienie: „Mając świadomość znaczenia moich słów i odpowiedzialności przed prawem, ślubuję uroczyście, że powierzone mi obowiązki w postępowaniu upadłościowym lub restrukturyzacyjnym będę wypełniać sumiennie i bezstronnie, dochowując tajemnic prawnie chronionych oraz kierując się w swym postępowaniu zasadami godności, uczciwości i etyki". W ślubowaniu widać między innymi wyraźne odwołanie do jednej z zasadniczych cech zawodów zaufania publicznego, jakim jest przestrzeganie zasad etyki.

Pomimo zawartego w treści ślubowania obowiązku zachowania tajemnic prawnie chronionych nie można powiedzieć, aby ustawodawca nakładał na doradcę restrukturyzacyjnego obowiązek zachowania tajemnicy zawodowej w zakresie, jaki obowiązuje adwokatów czy radców prawnych. Niemniej jednak dowodzi się, że obowiązek taki powinien istnieć ze względu na społeczną funkcję tego zawodu ${ }^{56}$.

Przykładem zawodu podobnego do zawodu doradcy restrukturyzacyjnego, który jest uznany za zawód zaufania publicznego, jest zawód komornika sądowego. Świadczy o tym między innymi forma uregulowania tego zawodu w Ustawie z dnia 22 marca 2018 r. o komornikach sądowych ${ }^{57}-\mathrm{w}$ rozdziale 10 tego aktu określono kształt i formę samorządu zawodowego. Ponadto o takim charakterze tego zawodu wskazuje „posiadanie wysokich kwalifikacji zawodowych, konieczność stosowania się do norm deontologicznych czy realizowanie tzw. misji społecznej, znajdującej odbicie w ochronie praw stron postępowania egzekucyjnego" 58 . Potwierdzenie statusu komornika sądowego jako zawodu zaufania publicznego można znaleźć także w orzecznictwie Trybunału Konstytucyjnego ${ }^{59}$.

${ }^{56}$ M. Waberski, op. cit., s. 71.

${ }^{57}$ Tekst jedn. Dz.U. 2021, poz. 850.

${ }^{58} \mathrm{~K}$. Kosiński, Rola samorządu zawodowego komorników sądowych w demokratycznym państwie prawnym, „Przegląd Prawa Egzekucyjnego” 2016, nr 6, pkt 4.

${ }^{59}$ Wyrok TK z 3 XII 2003 r., sygn. K 5/02, OTK-A 2003, nr 9, poz. 98, pkt III.5; wyrok TK z 14 XII 2010 r., sygn. K 20/08, OTK-A 2010, nr 10, poz. 129, pkt III.5.1. 


\section{Podsumowanie}

Doradcy restrukturyzacyjnemu, podobnie jak komornikowi sądowemu, powierza się zadania o szczególnym charakterze. Wpływają one na realizację zarówno interesu prywatnego wierzycieli, jak i interesu publicznego państwa. Należy więc wskazać, że obecny kształt zawodu doradcy restrukturyzacyjnego pozwala przyjąć, iż jest to zawód zaufania publicznego. Zawód ten do swojej działalności potrzebuje samorządu zawodowego, na który nałożone zostałyby obowiązki regulacyjne, orzecznicze, kontrolne i sprawozdawcze. Aby wypełnić te obowiązki, niezbędne jest też powierzenie takiemu podmiotowi wykonywania funkcji władztwa publicznego w imieniu własnym.

Zawód doradcy restrukturyzacyjnego jest jednym z newralgicznych elementów bezpieczeństwa obrotu gospodarczego. Pomimo tak istotnej pozycji sprawowanie np. funkcji syndyka nie jest wystarczająco określone, chociażby z punktu widzenia zasad wykonywania zawodu. Istniejące próby uregulowania działalności tej grupy zawodowej w sensie deontologicznym są niewystarczające. Wagę takich uregulowań w zakresie prawa upadłościowego i restrukturyzacyjnego widać w cytowanym powyżej ustawodawstwie Unii Europejskiej. Jednolity kodeks etyki wykonywania zawodu doradcy restrukturyzacyjnego wpłynąłby pozytywnie na całość postępowań upadłościowych i restrukturyzacyjnych.

Stworzenie takich norm związane jest ściśle $\mathrm{z}$ istnieniem samorządu zawodowego. W ocenie Trybunału Konstytucyjnego zakres pieczy nad należytym wykonywaniem zawodu zaufania publicznego powinien być rozumiany szeroko i obejmować między innymi kwestie ustalenia zasad etyki zawodowej ${ }^{60}$. Tworzenie takich zasad ma cechy zadania o charakterze publicznym, ale posiada też cechy zadania korporacyjnego ${ }^{61}$. W związku z tym $\mathrm{w}$ celu całościowego określenia zasad wykonywania zawodu przez doradców restrukturyzacyjnych niezbędny jest element samorządu zawodowego, wykonującego zadania publiczne i posiadającego uprawnienia władcze w stosunku do swoich członków.

\footnotetext{
${ }^{60}$ Wyrok TK z 30 XI 2011 r., sygn. K 1/10, OTK-A 2011, nr 9, poz. 99, pkt III.2.2.

${ }^{61} \mathrm{H}$. Izdebski, Sprawowanie pieczy nad należytym wykonywaniem zawodu przez samorzady zawodowe, w: Zawody zaufania publicznego a interes publiczny..., s. 36.
} 


\section{PROSPECTS FOR DEVELOPMENT OF THE PROFESSION OF RESTRUCTURING ADVISOR}

\section{S u m mary}

This paper aims to determine the directions of development of the profession of restructuring advisor in Poland. The analysis of the law regulating this profession will help answer the question of whether in its present form the profession of restructuring adviser has the character of a profession of public trust in accordance with Article 17(1) of the Polish Constitution. These findings are important for determining whether the legislator should create a self-governing body of restructuring advisors, which should be a key element in establishing the principles of the profession. A direction of the discussion defined in such a way first requires a historical and legal analysis of the legislation relating to a bankruptcy administrator. This analysis culminates in a description of the process of transformation of the profession of a bankruptcy administrator into the profession of a restructuring advisor and an analysis of the current legislation, which allows determining the nature of the profession of restructuring advisor.

The paper deals with the issues of how the professional self-government functions, and the ethics of the profession of restructuring adviser. It discusses the problems of currently operating organizations bringing together persons performing the profession of restructuring adviser, their status, and the validity of the legal acts issued by these entities.

The above remarks on Polish legislation are contrasted with the legal situation in the Federal Republic of Germany to show the extent of the changes in this legislation in Poland over the last thirty years.

In this article, attention is drawn to the need to enact additional legislation in this field in Poland. Future directions of the development of the profession of restructuring advisor as a profession of public trust are also evaluated through an analysis of both Polish constitutional law and European Union law, in particular, Directive 2019/1023 of the European Parliament and the Council relating to restructuring and bankruptcy.

Keywords: Official Receiver of a Bankruptcy Estate - restructuring adviser - professional self-government

\section{LITERATURA}

Adamus R., Zarys historii źródeł prawa upadłościowego w Polsce, "Jurysta" 2009, nr 7. Allerhand M., Prawo upadłościowe z komentarzem, Bielsko-Biała 1994.

Andres D., §56, w: Insolvenzordnung, pod red. D. Andresa, R. Leithausa, München 2014. Broll J., Prawo upadtościowe w świetle praktyki sądowej, Warszawa 1995.

Dąbrowski K., Samorzad zawodowy i gospodarczy, w: Administracja publiczna i prawo administracyjne w zarysie, pod red. M. Karpiuka, J. Kowalskiego, Warszawa 2013. 
Delhaes W., Römermann V., §56, w: Insolvenzordnung Kommentar, pod red. J. Nerlicha, V. Römermanna, München 2018.

Feliga P., Stanowisko prawne syndyka w procesie dotyczacym masy upadłości, Warszawa 2013.

Foerster U., Insolvenzrecht, München 2014.

Frind F., Zur Geltungsreichweite und Nutzen einer Berufsverordnung für Insolvenzverwalter, NZI 2018.

Gil I., Sytuacja prawna syndyka masy upadłości, Warszawa 2006.

Gnys A., Konsekwencje wejścia w życie ustawy o licencji syndyka, "Monitor Prawniczy” 2008, nr 5.

Gudowski J., Art. 87, w: Kodeks postępowania cywilnego. Komentarz, t. 1: Postępowanie rozpoznawcze, pod red. T. Erecińskiego, Warszawa 2016.

Hrycaj A., Syndyk masy upadłości, Poznań 2006.

Izdebski H., Sprawowanie pieczy nad należytym wykonywaniem zawodu przez samorzady zawodowe, w: Zawody zaufania publicznego a interes publiczny - korporacyjna reglamentacja versus wolność wykonywania zawodu, Warszawa 2002.

Jacyszyn J., Syndyk masy upadłości, „Rejent” 1993, nr 3-4.

Kosiński K., Rola samorządu zawodowego komorników sądowych w demokratycznym państwie prawnym, „Przegląd Prawa Egzekucyjnego” 2016, nr 6.

Kruth C., Insolvenzverwaltung - Closed Shop für Juristen?, DStR 2018.

Kulesza M., Pojęcie zawodu zaufania publicznego, w: Zawody zaufania publicznego a interes publiczny - korporacyjna reglamentacja versus wolność wykonywania zawodu, Warszawa 2002.

Podel W., Geneza instytucji syndyka masy upadłości na tle rozwoju regulacji prawa upadłościowego, "Rocznik Towarzystwa Naukowego Płockiego” 2013, nr 5.

Pokora A., Stanowisko prawne syndyka masy upadłości, „Rejent” 1997, nr 7-8(75-76).

Szydło M., Art. 17 Konstytucji RP, w: Konstytucja RP. Komentarz do art. 1-86, pod red. M. Safjana, L. Boska, Warszawa 2016.

Trubalski A., Samorzady zawodów zaufania publicznego na przykładzie samorządu radców prawnych, "Studia Iuridica Lublinensia” 2014, nr 21.

Vallender H., Die Zeit ist reif - Plädoyer für eine Berufsordnung für Insolvenzverwalter, NZI 2017.

Waberski M., Tajemnica zawodowa doradcy restrukturyzacyjnego, "Palestra” 2018, nr 7-8.

Wojtczak K., Zawód i jego prawna reglamentacja. Studium z zakresu materialnego prawa administracyjnego, Poznań 1999.

Wołpiuk W.J., Zawód zaufania publicznego z perspektywy prawa konstytucyjnego, w: Zawody zaufania publicznego a interes publiczny - korporacyjna reglamentacja versus wolność wykonywania zawodu, Warszawa 2002.

Zięba-Załucka H., Samorząd zawodowy w świetle Konstytucji RP, „Monitor Prawniczy” 2005, nr 10. 